\title{
SUBJETIVIDADES
}

Edição Especial:

A Psicanálise e as Formas do Político

e-ISSN: 2359-0777

\section{SOBRE A CRÍTICA DA PSICANÁLISE ÀS POLÍTICAS XENOFÓBICAS E SEUS DISPOSITIVOS DE PODER: SEGREGAÇÃO E GENOCÍDIO}

On the Criticism of Psychoanalysis to Xenophobic Policies and their Devices of Power: Segregation and Genocide

Sobre la Crítica del Psicoanálisis a las Políticas Xenofóbicas y sus Dispositivos de Poder: Segregación y Genocidio

\section{Sur la Critique de la Psychanalyse aux Politiques Xénophobes et ses Dispositifs de Pouvoir: De la Ségrégation et du Génocide}

DOI: $10.5020 / 23590777 . r s . v 18$ iEsp.6447

\section{Betty Bernardo Fuks (Lattes)}

Psicanalista. Dra. em Comunicação e Cultura (UFRJ). Pesquisadora do CNPQ. Professora do Mestrado e Doutorado em Psicanálise, Saúde e Sociedade (Universidade Veiga de Almeida). Pesquisadora do Laboratório de Psicopatologia Fundamental. E, Editora da revista online Trivium: estudos interdisciplinares.

\section{Resumo}

\begin{abstract}
A finalidade deste ensaio é retornar à incursão de Freud no campo da política, refletir sobre o conjunto de conceitos metapsicológicos que sustentou sua análise em relação à ideologia nazista de identidade racial e avaliar a pertinência desse conjunto para a crítica atual da psicanálise em relação aos fenômenos sociopolíticos. Para tanto, recorremos também aos aportes teóricos de Lacan, que permitem mostrar o ponto em que a ética da psicanálise é fundamental à teoria da política.
\end{abstract}

Palavras-chave: identificação; clivagem do eu; política; ética da psicanálise.

Abstract

The purpose of this essay is to return to Freud's incursion into the field of politics, to reflect on the set of meta-psychological concepts that supported his analysis of the Nazi ideology of racial identity and to evaluate the pertinence of this set to the current criticism of psychoanalysis in relation to phenomena sociopolitical. For this, we also resort to Lacan's theoretical contributions, which allow us to show the point at which the ethics of psychoanalysis is fundamental to the theory of politics.

Keywords: identification; cleavage of the self; policy; ethics of psychoanalysis.

\section{Resumen}

El objetivo de este ensayo es volver a la incursión de Freud en el campo de la politica, para reflexionar sobre el conjunto de conceptos metapsicológicos que sujetó su análisis en relación a la ideología nazi de identidad racial y evaluar la pertinencia de este conjunto para la crítica actual del psicoanálisis en relación a los fenómenos socio-políticos. Para eso, recurrimos también a los aportes teóricos de Lacan, que permiten enseñar el punto en que la ética del psicoanálisis es fundamental a la teoría de la política.

Palabras clave: identificación; división del yo; politica; ética del psicoanálisis. 


\section{Résumé}

Le but de cet essai est de retourner à l'incursion de Freud dans le domaine de la politique, bien comme réflél'chir sur l'ensemble des concepts metapsychologiques qui a soutenu son analyse par rapport l'idéologie nazie d'identité raciale. On a comme l'objectif, encore, évaluer de la pertinence de cet ensemble pour la critique actuelle de la psychanalyse par rapport aux phénomènes sociopolitiques. À cette fin, on a utilisé la théorie de Lacan, qui permet de montrer le point où l'éthique de la psychanalyse est fondamentale pour la théorie de la politique.

Mots-clés: identification; clivage du moi; politique; éthique de la psychanalyse.

A obra O homem Moisés e a religião monoteístal - Três ensaios (1939/2014b), de Sigmund Freud, é considerada seu testamento às futuras gerações de analistas pelo fato de explorar a teoria freudiana desde o começo e pelo conjunto de ideias que revelam a relevância da psicanálise na crítica à política de segregação. Aqueles que explicam a obra pelo homem costumam situar o texto em função da condição de judeu do autor, em meio à ascensão do nazismo, como uma espécie de contingência de sua própria história. É possível aceitar essa leitura desde que situemos Moisés como uma obra que se esclarece à luz dos conceitos psicanalíticos que a animam. O presente artigo seguirá as duas vias de leitura.

Moisés pertence à linhagem de escritos que reconduziram alguns pensadores do início do século XX à experiência escriturária milenar da história do povo judeu em face de perdas e infortúnios. A escrita é, na sua origem, a linguagem do ausente. Ela repara uma perda (Freud, 1930/2010) procurando inscrever o que já não está lá. É a esse princípio que Freud consigna a relação do judeu com a escrita numa carta de amor à Martha Bernays, sua futura mulher: "E os historiadores dizem que, se Jerusalém não tivesse sido destruída, nós, judeus, teríamos perecido como tantos outros povos. O edifício invisível do judaísmo só se tornou possível depois do desmoronamento do Templo visível” (Freud, 1960/1982, p. 39). O Antigo Testamento, suporte permanente, junta o povo judeu na diáspora. Essa tradição foi retomada por ocasião da escalada do antissemitismo, que acreditava saber o que era um judeu. Assim, a prática de leitura-escritura da Bíblia se estendeu ao universo da geração de intelectuais da mais nobre ascendência iluminista, assimilada, mas paradoxalmente marginalizada. Uma intelligentsia pária, no dizer de Hannah Arendt (1975, p. 68), anticonformista e revolucionária, mas que soube testemunhar, diante do preconceito elevado à categoria de arma ideológica, a impossibilidade de designar o ser judeu por meio da construção de judeidades, ato político que nomeia como cada sujeito vive sua condição de judeu (Fuks, 2000, p. 11).

Uma das primeiras notícias que temos sobre o Moisés está registrada numa carta a Arnoldo Zweig, na qual Freud formula a seguinte questão: "Diante das novas perseguições, como os judeus se tornaram o que são e por que atraem para si o ódio eterno?" (Freud \& Zweig, 1974, p. 98); questão muito antiga. O problema da persistência do nome judeu e a continuidade dos ódios que desperta dominaram o pensamento iluminista europeu (Milner, 2007, p. 11). Freud retoma a questão com a ascensão do nazismo e se encarrega de respondê-la sabendo de antemão que é próprio de toda questão permanecer aberta. Por outro lado, enquanto fundador da psicanálise, fez questão de construir uma resposta com a marca da metapsicologia, de modo a não ser transformada numa visão de mundo. Ideologias, quaisquer que sejam, sempre atentam contra a condição de pensar uma resposta como reiteração do enigma. Podemos então dar ênfase ao fato de que a obra de 1939 é expressão do momento histórico-político em que foi escrita e, ao mesmo tempo, testemunha do progresso de uma disciplina cujos conceitos estarão sempre em movimento.

Recolocada nesse quadro, concordamos com a avaliação de Michel de Certeau (1982) de que a regra da escrita de Moisés é o quiproquó, um estar no lugar do outro: é impossível reduzir a registros diferentes as presenças da figura bíblica, do judeu e do próprio Freud. Parafraseando o dito de Certeau, diria que é impossível dissociar o estudo dos conceitos teóricos que povoam o texto - trauma, negação, desmentido, cisão do eu e identificação - do contexto histórico, social e político em que foi escrito. Em outras palavras, se a contingência histórico-política tem um peso relevante na escrita da obra de 1939, no cômputo geral, isso se deve à importância das ferramentas teóricas que a atravessam.

Cabe dizer também que Moisés é uma obra aberta. Os múltiplos sentidos que borbulham ao longo dos três ensaios não se prestam à captura (Fuks, 2000, p. 87). Com estilo inconfundível, Freud reelabora, através de uma narrativa, a metapsicologia - os princípios do funcionamento do aparelho psíquico e o mito do assassinato do pai, dando sequência ao pensamento sobre a intolerância, exposto em escritos que testemunham a incursão da psicanálise na política de seu tempo (Comentário sobre el antissemitismo (1938/1976a); Psicologia das massas e Análise do Eu (1921/2013b); O mal-estar na cultura (1930/2010) e Por qué la guerra? (1933/1976b)), toma como ponto de partida, como já dito, um assunto que lhe era bastante familiar: o ódio ao judeu. 
Entretanto, as reflexões sobre o tema do antissemitismo alcançam um escopo maior: o universal horror à diferença que habita a alma humana. Em plena escalada do nazismo, perscrutar as exigências próprias do pulsional no político confirmava sua percepção de que a vida política pode tornar sinistro e funesto o exercício de amor entre idênticos e o endereçamento do ódio ao outro. Metáfora do excluído, a figura do judeu em Moisés expõe a verdade da rejeição feroz ao outro odiado.

Para uma maior precisão na execução da proposta, é preciso fazer um breve retorno ao início da psicanálise, ao tempo em que todos os aspectos da vida social, bem como o mundo das ideias, sofriam transformações. A modernidade chega derrubando muitos preconceitos e desconstruindo uma tradição de alguns séculos no campo da arte e da literatura. Como qualquer outra época em que o fluxo do "tornar-se" moderno invade a cultura, os movimentos da vanguarda modernista provocavam mutações, angariando fortes simpatias, mas sendo muitas vezes identificados como agentes de destruição da ordem. Segundo a tese do crítico literário Jacques Le Rider (1992), o jogo interminável entre a ordem e a desordem social, que ocorria em Viena nessa época, provocou uma explosão generalizada de "crises de identidade" no sujeito, no conjunto deles e, sobretudo, no que define este conjunto: a cultura.

Numa análise instigante de obras literárias e artísticas representativas do final do século XIX e do início do século seguinte, Le Rider mostra que a chegada tardia da modernidade à capital austríaca, se comparada à situação de cidades como Berlim e Paris, antecipou a temática dos processos político-identitários que informam a questão da subjetividade na contemporaneidade. Para o crítico literário, Freud teria, ao alocar o tema das identificações no centro da teoria do inconsciente, não apenas construído um novo modelo de apreensão do indivíduo, mas também criado ferramentas precisas para interrogar a heterogeneidade constitutiva do coletivo.

De fato, ao introduzir em uma linguagem específica o conceito de identificação, a partir do questionamento das noções de permanência, continuidade e coesão tradicionalmente ligadas à categoria filosófica de identidade, a psicanálise desvelou o seu caráter ilusório. A rigor, Freud (desde sempre um "cientista da alma" e contrário ao privilégio dado pela ciência positivista à coerência e à identidade como formas de verdade) descreveu o fato da identificação como uma "multiplicidade de pessoas psíquicas" (Masson, 1985/1986, p. 242) que constituem o Eu. Desde então, o múltiplo ganha um lugar especial no centro de sua teoria, e a identidade, a categoria que confere a alguém uma essência, ou que permite afirmar duas pessoas ou coisas como iguais, passa a ser problematizada. O conceito de identificação pressupõe uma impossibilidade de realização de qualquer identidade fixa e imutável.

Jean Florence (1994), no texto canônico "As identificações", mostra que o caráter que Freud imprime à identificação é processual e inacabado, o que corresponde à ideia de que o sujeito é marcado pelo Outro, pelo heterogêneo em relação a si mesmo. Outro pré-histórico e inesquecível Das Ding, a Coisa, jamais será reencontrado, embora o sujeito insista em buscálo fazendo do impossível reencontro a mola de seu desejo (Lacan, 1969/70/1992, p. 68). Assim, a insistência de Freud no papel das identificações na formação do Eu tornou a psicanálise uma disciplina totalmente voltada à alteridade, o que obriga seus herdeiros a sustentarem, na prática e na teoria, que o sujeito do inconsciente não se enquadra na sua própria categoria.

A elaboração do conceito de identificação na obra freudiana compreende um longo período de desenvolvimento que abrange desde o início até o final., sendo que, tanto em $A$ interpretação dos Sonhos (1900/2014a) quanto em $O$ homem Moisés (1939/2014b), Freud mobilizou suas próprias identificações, conforme se lê em ambos os textos, para levar adiante esse conceito central da psicanálise. Um olhar atento sobre A interpretação dos Sonhos (1900/2014a) penetra diretamente na exposição de suas experiências psíquicas em pleno caldeirão político da Viena no fin de siècle, sobre o qual foram assentadas as bases teóricas do conceito de identificação. No cômputo geral, Freud expõe uma série de sonhos próprios que dão corpo à expressão "multiplicidade de pessoas psíquicas", colocando em evidência a coexistência de identificações contraditórias em nossa terra de asilo interior, o inconsciente.

A rigor, as identificações inconscientes não cessam de demonstrar a verdade de que o eu é estrangeiro em face de si mesmo. Portanto, é mais do que legítimo dizer que a psicanálise, desde seus primórdios, subtrai a importância da noção de idêntico e faz valer a condição de estrangeiro como prerrogativa de todos. Aí estão os alicerces dos dois primeiros ensaios da obra de 1939, um estudo eminentemente histórico sobre a origem estrangeira do povo judeu em que, à luz do estudo psicanalítico exposto no terceiro ensaio, é possível apreender a genialidade com que Freud amplia a condição de estrangeiro do sujeito: a identidade de um povo advém de fora. O primeiro ensaio, "Moisés, o egípcio", é uma afirmativa que exigiu do pai da psicanálise confessar, logo nas primeiras linhas, estar tomado pela angústia de "privar um povo do homem que celebra como o maior de seus filhos" (Freud, 1939/2014b, p. 35) - tarefa que diz não empreender de bom grado, principalmente pelo fato de pertencer a esse povo. Trata-se de desconstruir uma identidade: Moisés, o legislador e fundador do monoteísmo, era um estrangeiro, um fora do lar judeu.

A ideia do estrangeiro na constituição do psiquismo havia sido introduzida desde o Projeto para uma psicologia cientifica (Freud, 1950/1976c): o grito de socorro da criança em sua entrada no mundo é dirigido ao Outro, estrangeirosemelhante. Este é o parâmetro básico da constituição do psiquismo que Freud estenderá ao coletivo em Moisés. Para 
tanto, era necessário decifrar as deformações (Entstellung) ${ }^{2}$ da escrita bíblica e as da literatura histórica sobre a origem do judaísmo. Assim, persegue o desmentido que recai sobre a origem estrangeira de Moisés e, mesmo tendo chegado a uma conclusão satisfatória sobre a origem egípcia de Moisés no mito do nascimento do herói de Otto Rank, reconhece que as primeiras conclusões, que poderiam conferir o estatuto de verdade histórica à sua hipótese, não resistem à prova.

No segundo ensaio, cujo título está devidamente registrado no condicional, "Se Moisés fosse um egípcio", Freud,(1939/2014b) se dá conta de que o terreno no qual percebe estar entrando, o da probabilidade, "não é necessariamente o verdadeiro e a verdade nem sempre é provável" (p. 45), principalmente quando se trata de desvelar restos que sinalizam o que se tentou apagar na escrita. As distorções do texto bíblico indicam que houve uma tentativa de fazer desaparecerem as marcas da verdade sobre a origem do povo judeu de maneira semelhante ao que se faz num crime, no qual "a dificuldade não está na execução do ato, e sim na eliminação de seus rastros" (p. 76). Freud toma como referência, como no primeiro ensaio, trabalhos de historiadores de sua época. Mas é precisamente ali, onde encontra certo número de fatos desmentidos, que a construção da origem estrangeira do judaísmo se impõe. O desmentido é um sinal de que algo, pelo efeito das distorções (Entstellung), foi interrompido no texto escrito. Como observa Brigitte Lemérer (1999), "é dessa maneira que Freud trabalha como analista, e é igualmente desse modo que ele previa a construção da teoria" (Lemérer, 1999, p. 44).

A tese sobre a origem estrangeira de Moisés implica a necessidade de seu assassinato, pois "depende do apoio de mecanismos metapsicológicos que o autor da obra importa do exterior ao escrito bíblico" (Rabinovitch, 2000, p. 47). Freud, um pensador em exílio, em êxodo, estrangeiro em face de si mesmo, insiste em resolver certo número de lacunas e de enigmas que o impedem de confirmar sua hipótese de que "os judeus são judeus em Moisés, que não o é" (Karsenti, 2012, p. 13). Em suas leituras sobre o Êxodo, Freud encontra o livro de Sellin (1922), estudioso do texto bíblico da escola exegética alemã. Baseado em certas passagens de Oseas e outros profetas, Sellin sustenta que Moisés tinha sido assassinado num levante popular. De imediato, Freud subscreve essa interpretação, mesmo tendo aventado a probabilidade de não estar correta; afinal, era a peça do quebra-cabeça que faltava, principalmente porque coerente com o mito psicanalítico das origens. A partir desse ponto, retorna ao texto bíblico e, sem contradizer os resultados confiáveis da investigação histórica, começa a integrar a hipótese da condição egípcia de Moisés ao cenário de Totem e Tabu (1913/2013a). O mito do parricídio obtém um papel fundamental - da mesma maneira que o mito do nascimento do herói alcança, na construção da assertiva "Moisés, um egípcio". Sem esses arquivos, o "todo teria de permanecer sem ser escrito" (Freud, 1939/2014b, p. 93), isto é, a construção do texto teria naufragado, e tanto a verdade material colhida da literatura histórica quanto a narrativa bíblica permaneceriam letras mortas.

À hipótese de Sellin, Freud agrega o saber psicanalítico: os judeus repetiram o assassinato do pai da horda na pessoa de Moisés, mas, no lugar de rememorar, despertaram sua marca mnêmica reatualizando o crime em ato. Em seguida, porém, o povo desmente o ocorrido, eliminando os traços do assassinato - desmentido que Freud, por sua vez, desvenda nas deformações (Entstellung) do texto, nas lacunas existentes entre o êxodo (Moisés egípcio) e o compromisso de Cades (Moisés midianita).

Estabelecida a construção final, tudo o que é relativo à fundação do povo e do monoteísmo é duplicado: dois fundadores (Moisés egípcio e Moisés midianita), duas fundações do monoteísmo, dois deuses antinômicos: Jeová e Aton. Essa dimensão política do compromisso de Cades, destacada no texto freudiano, constitui um tecido muito particular pelo qual o autor não apenas revela o modo como diferentes tribos se transformam num só povo com uma história comum - mesmos ancestrais, mesmo país de origem e a mesma religião -, como também destaca a função da ação do desmentido do assassinato de Moisés: conservar o amor pelo grande homem representado no texto bíblico descendo das alturas. $\mathrm{O}$ desmentido funciona como representante do ato cometido pelo sujeito e expõe sua divisão radical.

\section{O Impossível da Identidade: De como Freud Respondeu à Política Racista do Partido Nazista}

Com base na leitura conduzida até agora, argumentawmos que o estrangeiro na constituição de uma identidade é o ponto em que O homem Moisés (1939/2014b) reitera o princípio psicanalítico de que a origem do sujeito, individual e coletivo, advém do Outro, do heterogêneo em relação a si mesmo; do estrangeiro como condição da identidade. As referências que Freud faz ao longo dos três ensaios à fundação do monoteísmo judeu não significam necessariamente que estivesse

\footnotetext{
2 A palavra distorção (Entstellung) aparece ao longo da obra de 1939 em referência aos efeitos do mecanismo de defesa do desmentido (Verleugnung). De fato, o desmentido produziu mudanças no dispositivo de interpretação psicanalítica, pois indica que houve "uma tentativa de apagar as marcas da verdade de maneira semelhante à que se faz num crime no qual a dificuldade não está na execução do ato, e sim na eliminação de seus rastros" (Freud, 1939/2014b, p. 76). A lição de Freud em sua última obra consiste em afirmar que "a palavra distorção (Entstellung) (...) não deveria significar apenas 'modificar a aparência', mas também 'colocar em outro lugar, deslocar para outra parte' Assim, em muitos casos de distorções de textos podemos contar o fato de encontrar c escondido em algum lugar aquilo que foi reprimido (Unterdrückte) e desmentido (Verleugnete), embora modificados e arrancados do contexto. Só que nem sempre será fácil reconhecê-lo". (Freud, 1939/2014b, p. 76).
} 
pensando um começo: na verdade, ele estava buscando uma não origem na origem, ao que se subordina uma nominação - um crime ou uma exclusão anterior a esse ato. A cisão do eu (Ichspaltung) correlata ao desmentido do crime impede definitivamente o sujeito, individual e coletivo, de constituir-se idêntico a si mesmo. Divisão insolúvel que condena o eu a adiar permanentemente sua realização. Jacques Lacan considera essa característica da condição humana como a verdade mais decisiva da descoberta freudiana e, a partir dela, extrai a concepção do lugar excêntrico da subjetividade expressa pelo neologismo ex-timidade (ex e íntimo).

Visto dessa maneira, podemos sustentar que, se em A interpretação dos Sonhos Freud (1900/2014a) já anunciava a excentricidade radical de si mesmo com que o homem se confronta, em $O$ homem Moisés (1939/2014b), prolongando a temática da identificação ao pai morto desenvolvida em Totem e Tabu (1913/2013a) e em Psicologia das massas e Análise do Eu (1921/2013b), nós nos encontramos frente a frente com o impossível da identidade no campo das formações coletivas. Assim, o conceito psicanalítico de identificação obtém um papel central na obra de 1939, finalizando a estruturação de um modelo epistemológico no qual a identidade nada mais é do que uma pluralidade de diferentes vínculos identificatórios, estabelecidos em função de uma perda fundamental que instaura o desejo. Nesse registro, conforme o que aprendemos no capítulo nono de Psicologia das massas e Análise do Eu (1921/2013b), a identificação com um traço único do objeto amado e perdido introduz o sujeito na ordem simbólica sob a forma de pura diferença, assegurando o por vir de uma série de outras identificações sob a influência atrativa do eu ideal e do ideal do eu. Conforme assinalou Burity, o sujeito freudiano "é um precipitado de práticas identificatórias, a identidade é um momento instável da prática de identificação" (Burity, 1997, p. 3).

Trata-se, por conseguinte, de defender a ideia de que, a rigor, o sujeito persegue uma identidade subjetiva identificandose com objetos coletivos que jamais chegam a recobrir sua falta constitutiva e a brindar imaginariamente (eu ideal) ou simbolicamente (ideal do eu) a completude real perdida. Não há nada no imaginário ou no simbólico que possa trazer uma solução à estranheza de si que advém da impossibilidade de completude. Dado de estrutura do psiquismo que jamais é totalmente descartado, razão pela qual a psicanálise entende que o anseio pelo todo se presta facilmente à manipulação de discursos utópicos e ilusórios, em si mesmos totalizantes.

Chegamos, assim, a um dos pontos em que é possível extrair da figura de Moisés, o egípcio, uma crítica à política ariana racista de forjar e impor ao povo alemão uma única identidade, pura e harmoniosa, com base no programa de exclusão do estrangeiro do solo e do sangue. A política de identidade instalada pelo Partido Nacional-Socialista dos Trabalhadores Alemães, mais conhecido como Partido Nazista, colocou em jogo algo que a clínica psicanalítica permite observar: a destruição do nó entre nome e carne da identificação primeira com o pai, motor das identificações simbólicas.

O antissemitismo - Freud reconhece claramente no texto - é um fenômeno complexo e amplo para ter como resposta uma só causa. As características mais marcantes do povo judeu foram sendo, ao longo dos séculos, manipuladas pelo outro até se transformarem em fonte do ódio. Mas o ponto que nos prende a atenção, nesse momento, circunscreve a política identitária nacional-socialista, que teve como seu complemento o racismo, vetor principal da ideologia nazista.

Nesse contexto, a desconstrução da figura do fundador do monoteísmo adquire, sem excluir outras interpretações, a dimensão de ato interpretativo. A despeito de todas as pressões sofridas, Freud desvela o ideal fantasmático de identidade harmônica, completa e sem rasura de seu tempo. Ideal esse que estava sendo imposto à custa da eliminação dos restos não ajustáveis ao projeto de uma sociedade sem Outro. O Estado, investido do poder de distinguir entre amigos e inimigos, passou a permitir o livre exercício da pulsão de destruição e de crueldade contra a "malvada" alteridade.

Assim, ao projeto nacional-socialista, que encontrou na ideologia nazista o seu complemento (o de implantar uma unidade ariana fundada na fantasia de um corpo primeiro de onde o povo alemão teria ascendido (Lacoue-Labarthe \& Nancy, 2002), Freud responde reafirmando a ideia de que a identidade de um indivíduo ou a de um povo, por se estruturar em torno da divisão radical e insolúvel - a Spaltung -, enquanto tal é impossível. Não sem razão, somos surpreendidos, em meio ao texto de 1939, por uma inusitada comparação entre a formação do povo judeu e a do povo alemão. Na história moderna, o exemplo mais impressionante de um tipo de fusão entre povos, como a que aconteceu na história do povo judeu em Cades, "foi criado pela Reforma, que, após um intervalo de mais de um milênio, trouxe novamente à luz a linha fronteiriça entre a Germania, que no passado fora romana, e aquela que permaneceu independente" (Freud, 1939/2014b, p. 70). Na referida passagem, extremamente concisa, há uma clara crítica à concepção nazista da ideia de ascendência de um corpo primeiro na origem da identidade ariana: por mais que se queira apagá-las, as identificações inconscientes não se perdem, retornam, "vêm à luz" (Fuks, 2014, p. 100).

Essa súbita comparação entre o povo judeu e o povo alemão, carregada de sentido em função do momento político que atravessava a cultura europeia quando da escrita de Moisés, leva o leitor, como sublinha Bruno Karsenti, "à gênese do princípio de nacionalidade na Europa moderna" (Karsenti, 2012, p. 124) e à sua política de identidade associada à xenofobia e seus derivados: racismo, moralismo e intolerância - moedas correntes do nacionalismo. Conhecemos a análise freudiana desse estado de coisas desde Psicologia das massas e Análise do Eu (1921/2013b), texto em que Freud demonstra que a coesão entre os membros da massa se dá necessariamente por força da convicção de cada um sobre o amor do líder - ponto de agregação que reduz o laço social ao apego especular e hipnótico -, em nome do qual virá a salvação do desamparo - uma 
operação que só tem pleno êxito se for possível apagar a ambivalência amor-ódio do interior da massa, mantendo o amor de si entre os idênticos e dirigindo o ódio ao outro estrangeiro, assegurando uma unidade coesa.

Por que o ódio garante a formação da massa e a constituição do eu? Deixemos a questão em suspenso e nos limitemos a identificar no fenômeno grupal aquilo que Freud chamou de "narcisismo das pequenas diferenças", base da constituição do "nós" e do outro. O termo "narcisismo" define a estrutura do amor; e o termo "pequenas diferenças" designa diferenças reais, mas não absolutamente regulares, que impedem o outro de ser um perfeito semelhante em relação ao grupo. Não se trata de uma diferença qualquer, mas daquela que produz estranhamento suficiente para lembrar a própria divisão do sujeito. Levando o fenômeno do narcisismo das pequenas diferenças ao paroxismo, desembocamos na segregação e no racismo, tal como os define a psicanálise: repulsa do sujeito (individual ou coletivo) ao que lhe é mais íntimo e familiar, mas projetado sobre o objeto externo a quem endereça o ódio. Esse potencial de exclusão, situado para além de uma diferenciação entre o "eu" e o "outro" ou entre o "nós" e os "outros", visa justamente eliminar a diferença.

Os judeus não são fundamentalmente diferentes dos povos que os acolhem, mas se diferenciam de uma "maneira indefinível, sobretudo em relação aos povos nórdicos, e a intolerância das massas, notavelmente, se manifesta de maneira mais forte contra pequenas diferenças do que contra diferenças fundamentais" (Freud, 1939/2014b, p. 131), mas o suficiente para contradizer a ideologia de pureza de sangue que, baseada numa tipologia referida ao sangue nórdico e ao solo alemão, atribuía enorme valor à ideia de honra à identidade racial. Com isso, o povo judeu e outros grupos passaram a constituir um alvo privilegiado da política de intolerância determinante do "nós, os arianos" e do "outro, não ariano". E não podemos esquecer o fato de que justamente nesse momento a ciência moderna estreava as primeiras manipulações efetivas do corpo humano, de braços dados com a política de Estado de transformar em realidade o projeto de uma "raça pura". Muito haveria para pensar e dizer sobre esse processo durante os anos em que o nazismo dominou grande parte da Europa na tentativa de extermínio da "raça impura"3. Lembrá-lo aqui serve para indicar que as reflexões em O homem Moisés (1939/2014b) sobre esse estado de coisas passam pela escuta dos destinos pulsionais da política de apagar a tradição de reconhecimento da identidade por meio da língua, como fazem notar Philippe Lacoue-Labarthe e Jean Luc Nancy (2002), insistindo em que a retórica nazi de sangue e solo tinha como meta fortalecer a ideia de que a raça e o povo se ligam a esses elementos.

O racismo se tornou o carro-chefe do nacionalismo alemão. Nas palavras de Hitler, "o eixo central do programa nacionalsocialista consiste em abolir o conceito liberal de indivíduo assim como o conceito marxista de humanidade e substituí-lo pelo de comunidade do Volk (povo) enraizado no seu solo e unido pelas cadeias do mesmo sangue" (Lacoue-Labarthe \& Nancy, 2002, p. 61). O resultado desse processo determinou, ainda que temporariamente, o solipcismo da identidade ao decretar a morte das múltiplas identificações simbólicas que alimentam o psiquismo.

\section{Identificação com o Sinthome: De como a Teoria Lacaniana Contribui para o Reconhecimento de Práxis Políticas Possíveis contra a Xenofobia}

Uma das atualidades da crítica psicanalítica à intolerância xenofóbica consiste em nos fazer pensar como, na contemporaneidade, identidades nacionais (ser "israelense", "brasileiro", "europeu", "americano" etc.) se prestam à rejeição de muitos. Vale questionar se os privilégios da cidadania, sempre passíveis de manipulação política pelos Estados, não pressupõem a violência negativa da exclusão do não idêntico, muito semelhante àquela dos anos 1930, quando teve início o confisco de direitos dos não arianos. É preciso tornar cada vez mais consciente a realidade dolorosa de que o mundo enfrenta, em novos termos, o mesmo problema de exclusão/inclusão do outro. $\mathrm{O}$ fato é que alguns Estados insistem, na atualidade, em gerar discursos hegemônicos, acirrando a exclusão do outro segundo a ideologia que defendem, afastando-se, assim, do projeto democrático que supostamente deveriam executar e proteger. A insistência em forjar novos arqui-inimigos conta a seu favor com o chamado direito dos cidadãos e tem como complemento o processo de demonização do outro, intrínseco à instituição da segregação e ao extermínio.

\footnotetext{
3 Para os estudos sobre o racismo implantado pelo regime nazista, recomendaria ao leitor, em especial, a obra de Michel Foucault (2005) Em defesa da Sociedade. Durante as aulas do curso do Collége de France (1975-76), o filósofo desenvolveu a ideia de que o "racismo assegura a função da morte na economia do biopoder, segundo o princípio de que a morte dos outros é o fortalecimento biológico da própria pessoa na medida em que ela é membro de uma raça ou de uma população, em que se é elemento numa pluralidade unitária e viva" (p. 308). Portanto, a especificidade do racismo moderno, diferentemente das relações políticas e/ou guerreiras, encontra-se na tecnologia do poder, o mecanismo que faz dos Estados racistas os mais assassinos de todos os tempos. É assim que Foucault mostrará que o nazismo levou ao paroxismo não apenas as regulamentações biológicas de proteção à saúde hereditária do povo alemão, a biopolítica, mas também o biopoder, o poder disciplinar: "Não há sociedade a um só tempo mais disciplinar e mais previdenciária do que a que foi implantada, ou em todo caso, projetada pelos nazistas" (p. 309).
} 
Se Freud chegou a intuir o horror que estaria por vir, a Shoa, ${ }^{4}$ em função do que viveu às vésperas de sua morte - a demonização do outro como parte do projeto de abolir a proibição simbólica do incesto em nome da "massa" de idênticos que foi progressivamente constituída no modelo do pai da horda -, Lacan (1968), numa referência profética quando da "Proposição de 9 de outubro de 1967" aos psicanalistas da Escola, chamou a atenção para o crescente avanço da segregação no seio de sociedades pós-holocausto até então insuspeitas, como, por exemplo, na instituição psicanalítica. Lacan chega também a prognosticar que a ciência moderna, cuja lógica discursiva prega a eugenia pelo "bem da humanidade", na trilha dos nazistas, fará da filiação, cada vez mais, um puro vínculo de sangue em detrimento da transmissão simbólica que atravessa as gerações de falantes.

Retornando, nesse momento, à questão da segregação exposta em O homem Moisés (1939/2014b), com base no que já foi desenvolvido neste trabalho, será o caso de insistir na ideia de que o antissemitismo, o antifeminismo, a homofobia e, mais recentemente, a islamofobia e a xenofobia contra refugiados que estão buscando abrigo na Europa, testemunham a encarnação da parcela da pulsão de morte, imune à simbolização, que historicamente é endereçada ao estrangeiro. Esse tipo de violência destrutiva contra o outro que nos confronta com o real de nossa condição inacabada se encaixa perfeitamente naquilo que Freud designou como a terceira fonte de sofrimento humano: a facticidade da relação entre os homens. Existiria uma saída para minorá-la?

Pouco antes de começar a escrever O homem Moisés, Freud (1939/2014b), numa carta a Einstein, coloca que o horror à guerra não é uma consequência da razão, mas uma decisão ética e estética. Dessa forma, a recusa à guerra manifestada pelos pacifistas, nas palavras de Freud, tornou-se uma intolerância constitutiva, uma idiossincrasia ampliada ao extremo (p. 198). Nesse caso, como observa Rey-Flaud (2002), Freud sustenta que a recusa à guerra manifestada pelos pacifistas "não significa recuo horrorizado das boas almas diante do espetáculo estético das atrocidades geradas pelo retorno à barbárie" (p. 66), e sim diz respeito à capacidade de sublimação e a decisões de ordem ética e estética que cada sujeito é capaz de desenvolver.

A sublimação ocupa um lugar particular no empreendimento de sustentação da cultura. Ela significa um progresso espiritual que determina, como lemos em O homem Moisés (1939/2014b), a capacidade humana de apreensão do real incognoscível (Fuks, 2014, p. 163-172). Portanto, a sublimação não deriva de um saber experimental, mas da presença da alteridade ou outridade. Nos termos de Lacan, a sublimação comporta a possibilidade de construir um edifício "material" em torno do reconhecimento do real, da falta que atravessa o sujeito e do campo social (Lacan, 1959/60/1991, p. 153). Nesse sentido, a sublimação se define como uma nova relação entre a pulsão e o vazio que cria um espaço ao irrepresentável de ser representado, ainda que de modo eventual e evanescente. Para que essa definição possa fazer eco à resposta de Freud a Einstein sobre os fundamentos éticos e estéticos na base do horror à guerra, vale lembrar que, na teoria lacaniana, a sublimação, categoria estética muito diferente da idealização, é abarcada pelo campo da ética da psicanálise e situada mais além da ética tradicional com determinadas concepções do bem.

Existe outro eixo da ética da psicanálise, aquele que implica a identificação do sujeito com o sintoma enquanto sinthome, sustentado pela definição lacaniana de final da análise e que se tornou relevante para a análise psicanalítica do político. O cientista político Yanni Stavrakakis (2007) é um dos autores contemporâneos que se servem desse eixo para apreender o sentido de alguns movimentos políticos contrários a regimes ideologicamente fundados na fantasia utópica de plenitude que anima os projetos políticos totalitários. No entender do autor, a identificação com o sintoma social, o outro excluído, não está dirigida propriamente à solução de conflitos, mas garante a realização de um gesto simbólico capaz de incorporar a responsabilidade ética de não se aderir à ideologia de clausura social propagada por Estados totalitários e até mesmo pelos democráticos. Stravakakis dá como exemplo uma manifestação antirracista em Atenas, na qual os participantes em coro gritavam: "Todos somos ciganos". O modo como ele lê esse slogan é bastante original e produz um efeito muito positivo na articulação entre psicanálise e política. Ao dizer "todos somos ciganos", escreve o cientista político, os atenienses elevam o sintoma, a verdade excluída do campo social, então estigmatizada como uma particularidade estranha, ao lugar do universal (Stavrakakis, 2007, p. 189). Assim, os manifestantes chegam ao ponto de identificação com aquilo que, até aquele momento, era sustentado pela exclusão ou pela eliminação.

A identificação com o outro excluído recupera a importância do aparelho conceitual psicanalítico para a análise da política atual, que ameaça cada vez mais o princípio organizador da democracia, o vazio constitutivo do campo social, em torno do qual os atores coletivos, para usar aqui uma noção do campo da teoria política, buscam soluções para os impasses inerentes à formação de qualquer comunidade, grupo, povo etc. Para ilustrar melhor este ponto, recorreremos a um fato real do cenário político contemporâneo.

Recentemente, a chegada de estrangeiros vindos do Oriente Médio e da África à Europa estampou o rosto da crueldade humana: a foto de uma criança morta encontrada numa praia da Turquia. O episódio emblemático da atual crise xenofóbica europeia revelou a urgência de a democracia estabelecer outros modos de lidar com esse sintoma social de nosso tempo,

4 Shoa: termo da língua hebraica usado para definir o holocausto do povo judeu na Segunda Guerra Mundial. 
os refugiados. Segregá-los em função do ideal de uma sociedade harmônica e utópica, sem conflitos e restos, preocupação maior de líderes políticos que querem impedir a livre circulação dos estrangeiros, causa tragédias desse porte que não estão longe de ser identificadas com o genocídio que banhou de sangue os quatro cantos da civilização durante a Segunda Guerra Mundial e com o que aconteceu em Ruanda mais recentemente. Um genocídio "soft", na medida em que a ordem de extermínio não foi oficialmente decretada, apesar de o número de refugiados mortos aumentar diariamente.

Reclamar por justiça para aqueles que, procurando escapar da morte, têm como resposta a resistência dos países mais civilizados do planeta, é uma responsabilidade de ordem ética que cabe aos sujeitos que reconhecem a gravidade do ato de segregar, que atenta contra a vida do outro. Esse argumento encontra base em Comentário sobre el antissemitismo (1938/1976a), contemporâneo à escrita de O homem Moisés (1939/2014b), no qual Freud insiste que um judeu não deve advogar em causa própria, de forma que caberia a um não judeu indignar-se publicamente contra o nazismo. Este poderia ter sido um ato efetivo do povo alemão: o repúdio às leis nazistas de segregação e de extermínio.

De acordo com esse paradigma, e tendo como norte o eixo da identificação com o sintoma da ética da psicanálise, pergunta-se se não seria o caso de criarmos um slogan para traduzir nossa indignação pela morte da criança afogada pela crueldade humana. Poderia ser "todos estamos mortos?", com certeza, mas não se quer deixar de mostrar outra face desse ato de identificação: a criança morta promove em nós o reconhecimento de que, no futuro, corremos o risco de nossos filhos se tornarem as próximas vítimas. É que, diante do cadáver do outro, como mostrou Freud em Totem e Tabu (1913/2013a), não temos outra escolha senão perceber nossa própria morte e daqueles que nos são caros.

Stavrakakis, Y. (2007). Lacan y lo político (1 ed.). Buenos Aires: Prometeo Libros.

\section{Referências}

Arendt, H. (1975). As origens do totalitarismo: Antissemitismo, instrumento de poder. São Paulo: Documentário. (Originalmente publicado em 1951).

Burity, J. A. (1997). Psicanálise, identificações e a formação de atores coletivos. Retrieved from www.biblioteca.clacso. edu.ar/brasil.

Certeau, M. (1982). A escrita da história. Rio de Janeiro:Forense Universitária. (Originalmente publicado em 1975).

Florence, J. (1994). As identificações. In G. Taillandier et al., As identificações na teoria e na clínica psicanalítica. Rio de Janeiro: Relume Dumará.

Freud, S., \& Zweig, S. (1974). Correspondência Freud-Zweig. Buenos Aires: Grancia. (Originalmente publicado em 1968).

Freud, S. (1976a). Comentário sobre el antissemitismo. In Obras completas de S. Freud (Vol. 22). Buenos Aires: Amorrortu Editores. (Originalmente publicado em 1938).

Freud, S. (1976b). Por qué la guerra? (Eintein y Freud).In Obras completas de S. Freud (Vol. 22). Buenos Aires: Amorrortu Editores. (Originalmente publicado em 1933).

Freud, S. (1976c). Projeto. In Obras completas de S. Freud (Vol. 1). Buenos Aires: Amorrortu Editores. (Originalmente publicado em 1950).

Freud, S. (1982). Correspondência de amor e outras cartas (1873-1939). Rio de Janeiro: Editora Nova Fronteira. (Originalmente publicado em 1960).

Freud, S. (2010). O mal-estar na cultura. Porto Alegre: L\&PM. (Originalmente publicado em 1930).

Freud, S. (2013a). Totem e Tabu. Porto Alegre: L\&PM. (Originalmente publicado em 1913).

Freud, S. (2013b). Psicologia das massas e Análise do Eu. Porto Alegre: L\&PM. (Originalmente publicado em 1921).

Freud, S. (2014a). A interpretação dos Sonhos. (Vols. 1 - 2). Porto Alegre: L\&PM. (Originalmente publicado em 1900). 
Freud, S. (2014b). O homem Moisés e a religião monoteísta. Porto Alegre: L\&PM. (Originalmente publicado em 1939).

Fuks, B. B. (2000). Freud e a judeidade: A vocação do exílio. Rio de Janeiro: Editora Zahar.

Fuks, B. B. (2014). O homem Moisés e o monoteísmo: O desvelar de um assassinato. Rio de Janeiro: Civilização Brasileira.

Foucault, M. (2005). En defesa da Sociedade: Curso do Collége de France (1975-76). (M. F. Galvão, Trad.. São Paulo: Martins Fontes. (Originalmente publicado em 1997)

Karsenti, B. (2012). Moïse et l'idée de peuple. Paris: Les Éditions du Cerf.

Lacan, J. (1968). Proposition du 9 octobre 1967 sur la psychanalyse de l’ École Freudienne. In Scilicet $n^{\circ}$ 1, ler trimestre 1968. Paris: Seuil, pp. 14-30.

Lacan, J. (1991). O Seminário, livro 7: A Ética da Psicanálise. Rio de Janeiro: Zahar. (Originalmente publicado em 1959/60).

Lacan, J. (1992). O Seminário, livro 17: O avesso da psicanálise. Rio de Janeiro: Zahar. (Originalmente publicado em 1969/70).

Lacoue-Labarthe, P., \& Nancy, J-L. (2002). O mito nazista. São Paulo: Iluminuras.

Lemérer, B. (1999). Los dos Moisés de Freud (1914-1939): Freud y Moisés, escrituras del padre I. Barcelona: Ediciones del Serbal. (Originalmente publicado em 1966).

Masson, J. M. (1986). A correspondência completa de Sigmund Freud para Wilhelm Fliess (1887-1904). Imago: Rio de Janeiro. (Trabalho original publicado em 1985).

Milner, J. C. (2007). Las inclinaciones criminales de la Europa democrática. Buenos Aires: Manantial.

Rabinovitch, S. (2000). Escrituras del asesinato: Freud y Moisés, escrituras del padre 3. Barcelona: Edicines del Serbal.

Rey-Flaud, H. (2002). Os fundamentos metapsicológicos de O mal-estar na cultura. In S. Freud. Em torno de O mal-estar na cultura, de Freud (1 ed., pp. 5-68). São Paulo: Editora Escuta.

Sellin, E. (1922). Mose und seine Redeutung für die israelitich-jüdische Religionsgeschichte [Moisés e sua importância para a história da religião judaica israelita]. Leipzig.

\section{Endereço para correspondência}

Betty Bernardo Fuks

Email: betty.fuks@gmail.com

Recebido em: 27/04/2017

Revisado em: 15/01/2018

Aceito em: 20/01/2018 